\title{
Potential Indicators Of Balance Sheet And Income Statement Fraud
}

\author{
Jeff Decker, California State University, Chico, USA
}

Tim Kizirian, California State University, Chico, USA

\begin{abstract}
This student case study is intended for use in the accounting classroom to develop a stronger understanding of potential fraud indicators and their level of significance. Auditing standard setters have responded to high profile accounting frauds by increasing the responsibility of auditors to find and report on accounting frauds. This case study presents a number of fraud indicators that can be investigated and discussed as part of a class assignment. This case study is unique in that it makes a clear differentiation between quality of revenue and quality of earnings.
\end{abstract}

Keywords: Auditing; Fraud Indicators; Risk Factors; Quality of Revenue; Quality of Earnings

\section{INTRODUCTION}

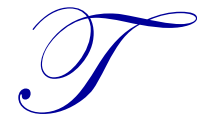

he Auditing Standards Board (ASB) issued Statement on Auditing Standards No. 99, Consideration of Fraud in a Financial Statement Audit (AICPA, 2002). This statement elevated the overall importance of considering the risk of fraud in all types of audits. Extant research and promulgation address the importance of considering the risk of fraud in the financial statements (e.g., Blay, Sneathen, Kizirian, 2007; Domino, Wingreen, Blanton, 2015; Kizirian, Mayhew, Sneathen, 2005; Metrejean, Orchard, Sneathen, 2007; PCAOB, 2007, 2014; Reffett, 2010). Students must be prepared to search for and understand the indicators that could be linked to fraud. Instructors can foster learning by providing students with a listing of fraud indicators and focus a discussion on the range of reasons that could have caused the indicators. In this case study we present a number of fraud indicators that can be investigated as part of a class assignment using both the balance sheet and income statement.

\section{STUDENT ENGAGEMENT USING A CASE STUDY}

This case outlines potential indicators of fraud relating to the balance sheet and the income statement. Balance sheet indicators are outlined in Section One while income statement indicators are outlined in Section Two (Quality of Revenue) and Section Three (Quality of Earnings). Students can be provided with the fraud indicators and utilize them in identifying the appropriate auditor consideration to take. This case provides the necessary learning tools for students to begin to comprehend the connection between various accounting irregularities and fraud.

This case can be implemented in the advanced auditing course as a take home problem or as an in-class discussion. We suggest providing students with the following:

Pretend that you are a first year auditor on a financial statement audit of a large publically traded corporation. The audit firm holds a fraud brainstorming session during the planning phase of every audit. Your manager highlights a number of balance sheet and income statement fraud indicators (provided below) that may need to be investigated. What are the possible reasons behind these fraud indicators?

Of course, the student answers to these questions will be varied. Our case analysis and discussion follows. 


\section{Section One: The Balance Sheet}

The first area for students to review is the balance sheet. The quality of numbers representing assets/liabilities are important as the basis for understanding a firm's financial position. The indicators are numbered only for identification purposes.

Indicators:

1. Cash and equivalents decline relative to total assets.

Indication of potential liquidity issue* or a quality of earnings issue (particularly in the event that the entity is incurring significant debt).

2. Receivables growing at a high rate.

Indication of potential current or future liquidity issue* as well as potential fictitious or premature recognition of revenue.

3. Bad debt reserves decline relative to gross receivables.

Potential misclassification of receivables or significant write-offs of receivables; potential understatement of reserves.

4. Bad debt reserves increase relative to gross receivables.

Potential indication of prior period revenue recognition problems or understatement of prior period reserves.

5. Inventory grows substantially faster than sales, cost of sales, or accounts payable.

Indication of a potential current or future liquidity issue* as well as potential manipulation of cost of goods sold/gross margin.

6. Inventory reserves decline relative to inventory.

Indication of a liquidity potential issue* if asset is used as collateral for borrowing/compliance with debt covenants. Also possible is the Potential understatement of obsolescence/excess charges as well as Potential manipulation of cost of goods sold/gross margin.

7. Property, plant and equipment declines sharply relative to total assets.

Indication of a potential liquidity issue* - failure to invest in plant and equipment. Also check potential "gross up" in another asset category.

8. Property, plant and equipment increases sharply relative to total assets.

Potential improper capitalization of expenses (e.g., Repairs, maintenance, small dollar items) in order to manipulate earnings growth.

9. Goodwill rises sharply relative to total assets without a corresponding business purchase transaction.

Potential reclassification of tangible assets to goodwill to avoid expensing them in future periods.

10. Other assets rise substantially relative to total assets.

Potential improper capitalization of certain operating expenses or a lack of appropriate provisions for amortization.

11. Growth in accounts payable is significant.

Indication of a potential liquidity issue* as well as potential indication that the recording of liabilities from prior periods may have been deferred to current period.

12. Accrued expenses decline relative to total assets. Potential manipulation of earnings (e.g., not recognizing expenses in a timely manner).

13. Significant or constant increases in total debt (long-term and short-term). Indication of potential liquidity issues*, also check potential quality of earnings concern (e.g., earnings have not been converted to cash resulting in the need to borrow to overcome the unrecognized losses).

*Liquidity issues culminate when considering whether the organization is a going concern. These issues can also be indicative of pressure on a firm that could lead to manipulation of the financial statements.

Balance sheet fraud can occur for a number of reasons. Students should check the notes of the financial statements and look for information about accounts. These can include checking for loan agreements that have assets used as 
collateral as well as loan agreements containing debt covenants. These situations can provide the pressure to commit fraud if agreements are in danger of being violated.

If indicators are found, additional attention must be given to accounts that may be affected, such as checking for fictitious inventory or receivables as well as shell games like "credit and rebill" in accounts receivable.

While these are directly related to the balance sheet, balance sheet fraud can occur indirectly due to income statement fraud. This can happen in a number of ways including:

- Improper revenue recognition that results in misstatements in accounts receivables and an increase in the aging of accounts receivables.

- Manipulation of cost of sales/gross margin that results in an overstatement of inventory as compared to total assets or sales (e.g., not taking obsolete inventory off the books or not matching expenses appropriately to revenue).

\section{Section Two: Income Statement (Quality of Revenue)}

While most financial statement frauds affect the balance sheet in one form or another, addressing income statement fraud can lead to early detection of many types of fraud/material misstatement. There are two areas where students should be aware related to income statement fraud: the quality of revenue and the quality of earnings. In this context, quality refers to the degree in which the reported numbers are a reasonable estimate of the true numbers. The following indicators are related to fraud connected to reported earnings.

Indicators:

1. Change in accounting principle, estimate or classification (e.g., Change to postpone revenue recognition until the channel sells to an end user; a change in reserve methodology that significantly increases reserves).

Potential concealment of prior period early revenue recognition or channel stuffing (e.g., Providing an incentive to channel partners - often through excessive discounts, lengthy payment terms, or rights of return/exchange - to accept more product than they can reasonably expect to sell in the short term).

2. Significant increases in revenue from prior year(s).

Potential early recognition, channel stuffing, and/or fictitious revenue often results in aging of receivables and/or higher volume of product exchanges/credit.

3. Significant decrease in revenue from prior year(s).

Prior period early revenue recognition or channel stuffing (e.g., Write-offs of account receivables, significant increases to reserves, and a large volume of credit memos, or returns of merchandise).

4. Significant decline in deferred revenue as a percentage of revenue.

Potential early recognition of revenue or a change in accounting methods.

5. Cost of sales significantly declines relative to sales.

Potential early recognition of revenue and/or fictitious revenue.

6. Increase in receivables turnover ratio.

Potential prior period early or inappropriate recognition of revenue (e.g., channel stuffing, fictitious revenue).

Students should consider the following when they have sufficient indicators:

1. Perform analytics on the aging of receivables by invoice date and by customer class (e.g., end user, channel, resellers).

Companies can prepare the receivables aging based on due date versus invoice date in order to mask the effect of extended payment terms. Performing analytics on receivables by invoice date ensures that the students will obtain a better condition of the true condition of receivables. 
Performing analytics of the receivables aging by customer class allows students to identify whether a certain type of customer class has been provided terms that vary significantly from other classes. If there are additional indicators present after performing the aging, it would then be appropriate to move to third party confirmation for customers receiving special terms.

2. Perform analytics on credits/returns/reshipments by customer class.

Students need to recognize that a company that has previously recognized revenue from fictitious sales or sales with rights of return may issue credit memos to remove the invoices from the receivables ledger prior to the end of the reporting period. These could take the form of (1) a "credit and rebill" to restart the aging process or (2) a credit for a stock exchange or rotation. Performing analytics on credits to the receivables ledger may provide the student with insight as to whether this condition may be present.

3. Electronically match the date of material invoices (or those for a specific type of customer class) for the prior quarter that is no longer on the receivables ledger to the payment date to identify those where payment significantly lagged.

Students should be aware that a company may anticipate the auditors will apply a higher level of scrutiny to sales that occur at the end of the reporting period and record sales in the middle of the reporting period to avoid detection. An example is a channel stuffing transaction made in the second month of the second quarter with net 30 terms, the invoice would appear only slightly overdue during the testing for the second quarter. If payment was received prior to the completion of the third quarter testing (120+ days out from initial sale), this transaction may avoid detection.

4. Identify whether assistance is provided to customers in obtaining financing to purchase product.

Some companies, in order to avoid scrutiny of their accounts receivables, may assist their channel partners in financing the purchase of their products. It may be difficult for auditors to discover as the receivables are paid with the proceeds of the financing. Students need to know that once again third party confirmation is a logical step to take in order to better understand the overall relationship with the company being audited.

5. Identify any revenue transactions that appear to be a barter or reciprocal in nature.

These types of arrangements could be indicative of fictitious revenue being generated through direct or indirect quid-pro-quo arrangements where similar entities agree to "buy" similar amounts of product from each other and to either simultaneously exchange cash or to offset the payable against the receivable. Students should realize that because these transactions are "paid" the auditor may not detect them.

\section{Section Three: Income Statement (Quality of Earnings)}

Also, directly related to income statement fraud and material misstatement is the quality of earnings. Students need to be aware of the indicators of earnings management and related audit considerations. These indicators follow.

Indicators:

1. Cost of sales fluctuates widely or fails to fluctuate from quarter to quarter relative to sales. Potential manipulation of cost of goods sold (e.g., Improper matching to sales, manipulation of inventory balances).

2. Cost of goods sold as a percentage of sales significantly increases.

Potential prior period manipulation of cost of goods sold (e.g., Improper matching to sales, manipulation of inventory balances, over-accrual of expenses to enhance future-period results).

3. Sales and general and administrative expenses significantly increase from prior years and/or relative to sales.

Potential prior period manipulation of sales, general and administrative expenses; over-accrual of expenses to enhance future period results. 
4. Depreciation/amortization expenses significantly increase from prior years and/or relative to sales.

Potential improper capitalization of fixed assets or intangible; change in methodology to enhance future period results.

5. Depreciation/amortization expenses significantly decreases from prior years and/or relative to sales.

Potential prior period improper capitalization of interest expense.

Review further for liquidity concern that assets may not be being replaced as they wear out.

6. Interest expenses significantly increase from prior years and/or relative to sales.

Potential prior period improper capitalization of interest expense. Review further for liquidity concern if substantial increases in debt levels are noted.

7. Interest expenses significantly decrease from prior years and/or relative to sales. Potential improper capitalization of interest expense.

8. Significant increase in other income.

Potential fictitious income. Review further for liquidity concern if large portion of earnings is nonrecurring.

Expenses should be examined to see that they are properly recorded/matched to the period in which they are incurred.

As students consider expenses, they should recognize that companies may hold expenses for a later period (which has the same effect as increasing income of the current period). Expenses could be listed on the balance sheet through improper capitalization, or not presented at all, due to failure to record accruals or "holding" invoices rather than properly entering them into the accounting system.

Improper capitalization of expenses should always be emphasized to students as a high risk possibility. Expenses often occur in increments over a period of time and therefore may not be evident through a year to year analytical review. Auditors should consider performing a trend analysis of an asset's growth over a longer period of time (i.e., 5 years) as compared to the trend in the related income account. Students should note that such an analysis will assist in identifying those accounts that have been building up on the balance sheet over time.

A company may manipulate inventory/cost of goods sold to achieve a double purpose - this manipulation increases both the gross margin and the overall earnings of the entity. Students should know that while any inventory item may be improperly capitalized, manufactured goods generally have greater potential to be improperly capitalized, given the number of judgments required for cost allocations, estimates, and overhead rates.

\section{CONCLUSION}

This case outlines potential indicators of fraud in the balance sheet and the income statement. Unique to this case is a differentiation between quality of revenue and quality of earnings. We suggest implementing this case by presenting students with fraud indicators, and then forming a discussion around the possible reasons behind the fraud indicators. While a wide range of possible reasons will be presented by students, we recommend that instructors emphasize the "worst case" scenarios that involve intentional misstatement. This learning tool can be used as an in-class case discussion or as a take home assignment for an advanced auditing course.

\section{AUTHOR BIOGRAPHIES}

Jeff Decker, Ph.D., CPA is an Associate Professor of Accounting at CSU, Chico. He has taught Managerial, Financial, Auditing and MBA accounting. His research focuses on issues relating to management's use of internal controls.

Tim Kizirian, Ph.D., CPA is a Professor of Accounting and Department Chair at CSU, Chico. He has taught Auditing, Forensic Accounting, and Financial Accounting. His research typically focuses on issues in audit planning and internal controls. 


\section{REFERENCES}

American Institute of Certified Public Accountants (AICPA). (2002). Consideration of Fraud in a Financial Statement Audit. Statement on Auditing Standards No. 99. New York, NY: AICPA.

Blay, A., Sneathen, L. D., \& Kizirian, T. (2007). The effects of fraud and going-concern risk on auditors' assessments of the risk of material misstatement and resulting audit procedures. International Journal of Auditing, 11(3), 149-163.

Domino, M. A., Wingreen, S. C., \& Blanton, J. E. (2015). Social cognitive theory: The antecedents and effects of ethical climate fit on organizational attitudes of corporate accounting professionals - A reflection of client narcissism and fraud attitude risk. Journal of Business Ethics, 131(2), 453-467.

Kizirian, T., Mayhew, B. W., \& Sneathen, L. D. (2005). The impact of management integrity on audit planning and evidence. Auditing: A Journal of Practice and Theory, 24(2), 49-67.

Metrejean, E., Orchard, L. X., \& Sneathen, L. D. (2007). The consideration of fraud in a financial statement audit: Some study questions. Journal of Business Case Studies, 3(1), 37-44.

Public Company Accounting Oversight Board (PCAOB). 2007. An audit of internal control over financial reporting that is integrated with an audit of financial statements. http://pcaobus.org/Standards/Auditing/Pages/Auditing_Standard 5.aspx

Reffett, A. B. (2010). Can identifying and investigating fraud risks increase auditors' liability? The Accounting Review, 85(6), 2145-2167. 